\title{
Luaran Ibu dan Perinatal pada Kehamilan dengan Preeklampsia Berat di RSUP Prof. Dr. R. D. Kandou Manado Periode 1 Januari - 31 Desember 2016
}

\author{
${ }^{1}$ Chaerul Kalam A. \\ ${ }^{2}$ Freddy W. Wagey \\ ${ }^{2}$ Suzanna P. Mongan
}

\author{
${ }^{1}$ Program Studi Pendidikan Dokter Fakultas Kedokteran Universitas Sam Ratulangi Manado \\ ${ }^{2}$ Bagian Obstetri dan Ginekologi Fakultas Kedokteran Unsrat \\ Email: chaerulkalam16@gmail.com
}

\begin{abstract}
Maternal mortality in Indonesia is still dominated by three main causes: bleeding (30.3\%), hypertension in pregnancy (27.1), and infection (7.3\%). Hypertension in pregnancy is one of the main causes for maternal and perinatal mortality and morbidity. This tsudy was aimed to obtain maternal and perinatal outcomes in pregnancies with severe preeclampsia (sPE) at Prof. Dr. R. D. Kandou Hospital Manado from January to December 2016. This was a descriptive retrospective study using patients' medical record data. The results showed that the characteristics of pregnant woman with sPE included mother age 20-35 years old (69.2\%), primigravida $(50.8 \%)$, pregnancy interval $\geq 5$ years $(65.6 \%)$, preeclampsia history $(25 \%)$, overweight (55.4\%), and history of chronic hypertension (10.8\%). The results of maternal outcomes included maternal mortality (1.5\%), HELLP syndrome (4.6\%), visual impairment (4.6\%), eclampsia $(6.2 \%)$, ICU care $(1.5 \%)$, and sepsis $(1.5 \%)$. The results of perinatal outcomes included perinatal mortality (4.6\%), IUGR (6.2\%), LBW (35.4\%), asphyxia (7.7\%), fetal distress (20\%), and prematurity (26.2\%). Conclusion: Maternal outcomes in pregnancy with sPE included mortality, HELLP syndrome, visual impairment, eclampsia, ICU care, sepsis meanwhile perinatal outcomes included perinatal mortality, IUGR, LBW, asphyxia, fetal distress, and prematurity.
\end{abstract}

Keywords: sPE, maternal outcome, perinatal outcome

\begin{abstract}
Abstrak: Kematian ibu di Indonesia masih didominasi oleh tiga penyebab utama yaitu perdarahan $(30,3 \%)$, hipertensi dalam kehamilan $(27,1)$, dan infeksi $(7,3 \%)$. Hipertensi dalam kehamilan merupakan salah satu penyebab utama mortalitas dan morbiditas pada maternal dan perinatal. Penelitian ini bertujuan untuk mengetahui luaran ibu dan perinatal pada kehamilan dengan preeklampsia berat (PEB) di RSUP Prof. Dr. R. D. Kandou Manado periode 1 Januari 2016 - 31 Desember 2016. Jenis penelitian ialah retrospektif deskriptif menggunakan data rekam medik pasien PEB. Hasil penelitian pada kehamilan dengan PEB memperlihatkan karakteristik usia ibu 20-35 tahun $(69,2 \%)$, primigravida $(50,8 \%)$, jarak hamil $\geq 5$ tahun $(65,6 \%)$, riwayat preeklampsia $(25 \%)$, overweight $(55,4 \%)$, dan riwayat hipertensi kronis $(10,8 \%)$. Luaran ibu meliputi mortalitas ibu $(1,5 \%)$, sindrom HELLP $(4,6 \%)$, gangguan penglihatan $(4,6 \%)$, eklampsia $(6,2 \%)$, rawat ICU $(1,5 \%)$, dan sepsis $(1,5 \%)$. Luaran perinatal meliputi mortalitas perinatal $(4,6 \%)$, IUGR $(6,2 \%)$, BBLR $(35,4 \%)$, asfiksia $(7,7 \%)$, gawat janin $(20 \%)$ dan prematur $(26,2 \%)$. Simpulan: Luaran ibu pada kehamilan dengan PEB berupa mortalitas, sindrom HELLP, gangguan penglihatan, eklampsia, rawat ICU, dan sepsis sedangkan luaran perinatal berupa mortalitas perinatal, IUGR, BBLR, asfiksia, gawat janin, dan prematur.
\end{abstract}

Kata kunci: PEB, luaran ibu, luaran perinatal 
Kematian ibu di Indonesia didominasi oleh tiga penyebab utama kematian yaitu perdarahan $(30,3 \%)$, hipertensi dalam kehamilan $(27,1)$, dan infeksi $(7,3 \%),{ }^{1}$ namun proporsinya telah berubah, perdarahan dan infeksi cenderung mengalami penurunan sedangkan hipertensi dalam kehamilan semakin meningkat. $^{2}$

Angka kematian bayi di Indonesia masih tergolong tinggi yaitu 22 per 1000 kelahiran hidup pada SUPAS 2015. ${ }^{3}$ Berdasarkan data program kesehatan anak Sulawesi Utara, terdapat 286 kasus kematian bayi dan 244 kasus kematian neonatal tahun 2015. ${ }^{4}$ Sebuah penelitian menemukan $95,5 \%$ penyebab kejadian lahir mati adalah komplikasi pada kehamilan dengan hipertensi maternal di posisi pertama $(23,6 \%){ }^{5}$

Hipertensi dalam kehamilan (HDK) adalah kondisi meningkatnya tekanan darah ibu hamil yang disertai dengan proteinuria yang merupakan komplikasi kehamilan dan menjadi salah satu penyebab utama mortalitas dan morbiditas maternal dan perinatal. $^{6}$

Komplikasi pada ibu yang mengancam jiwa pada preeklampsia yaitu ablasio plasenta, gagal ginjal akut, hemolysis, elevated liver enzymes and low platelet count (HELLP syndrome), konvulsi, edema pulmonar, dan kemungkinan komplikasi lainnya akibat sesaria. Dampak dari hasil luaran janin pada kehamilan dengan preeklampsia di antaranya prematuritas yang dapat dinilai berdasarkan uji Dubowitz, asfiksia berdasarkan penilaian APGAR, small for gestational age (SGA) menurut grafik Lubchencho, dan stillbirth. ${ }^{7-9}$

Berdasarkan data RSUP Prof. Dr. R. D. Kandou Manado, angka kejadian preeklampsia masih tergolong cukup tinggi. Pada tahun 2013 ditemukan 657 kasus preeklamsia $(\mathrm{PER}=452, \quad \mathrm{PEB}=205)$ dari 5.258 persalinan dan tahun 2014 sebanyak 201 kasus $(\mathrm{PER}=60, \mathrm{PEB}=109$, superimposed $\mathrm{PE}=32$ ) dari 3347 persalinan. ${ }^{10,11}$

\section{METODE PENELITIAN}

Jenis penelitian ini ialah retrospektif deskriptif, yaitu dengan menggunakan data rekam medik pasien PEB. Sampel penelitian ini ialah seluruh ibu hamil dengan PEB yang mempunyai data rekam medik lengkap di RSUP Prof. Dr. R. D. Kandou Manado periode 1 Januari 2016 31 Desember 2016.

\section{HASIL PENELITIAN}

Dari total 1081 persalinan di RSUP Prof. Dr. R. D. Kandou Manado periode 1 Januari 2016-31 Desember 2016, didapatkan 85 pasien ibu hamil dengan PEB. Dari jumlah tersebut terdapat 65 pasien yang memenuhi kriteria inklusi dan 20 pasien lainnya dieksklusi karena terdapat pasien dengan kehamilan ganda dan data rekam medik yang tidak lengkap. Berdasarkan Tabel 1, ibu hamil dengan PEB paling banyak pada usia ibu 20-35 tahun yaitu 45 orang $(69,2 \%)$.

Tabel 1. Hasil distribusi penderita PEB berdasarkan usia

\begin{tabular}{ccc}
\hline \multirow{2}{*}{ Usia } & \multicolumn{2}{c}{ PEB } \\
& $\mathbf{N}$ & $\mathbf{\%}$ \\
\hline$<20$ tahun & 6 & 9,2 \\
20-35 tahun & 45 & 69,2 \\
$>$ 35 tahun & 14 & 21,6 \\
Total & 65 & 100 \\
\hline
\end{tabular}

Berdasarkan Tabel 2, ibu hamil dengan PEB paling banyak pada ibu primigravida yaitu 33 orang $(50,8 \%)$.

Tabel 2. Hasil distribusi penderita PEB berdasarkan paritas

\begin{tabular}{ccc}
\hline \multirow{2}{*}{ Paritas } & \multicolumn{2}{c}{ PEB } \\
& N & \% \\
\hline Primigravida & 33 & 50,8 \\
Multigravida & 32 & 49,2 \\
Total & 65 & 100 \\
\hline
\end{tabular}

Berdasarkan Tabel 3, dari seluruh ibu hamil dengan PEB yang memiliki jarak kehamilan (multigravida $=32$ ), terbanyak pada ibu dengan jarak kehamilan $\geq 5$ tahun yaitu 21 orang $(65,6 \%)$.

Berdasarkan Tabel 4, dari seluruh ibu hamil dengan PEB yang memiliki riwayat 
kehamilan sebelumnya (multigravida $=32$ ), paling banyak pada ibu tanpa riwayat preeklampsia yaitu 24 orang $(75 \%)$.

Tabel 3. Hasil distribusi penderita PEB berdasarkan jarak antara kehamilan

\begin{tabular}{ccc}
\hline $\begin{array}{c}\text { Jarak antara } \\
\text { kehamilan }\end{array}$ & N & PEB \\
\hline$\leq 2$ tahun & 2 & 6,3 \\
$2-5$ tahun & 9 & 28,1 \\
$\geq 5$ tahun & 21 & 65,6 \\
Total & 32 & 100 \\
\hline
\end{tabular}

Tabel 4. Hasil distribusi penderita PEB berdasarkan riwayat preeklampsia kehamilan sebelumnya

\begin{tabular}{ccc}
\hline $\begin{array}{c}\text { Riwayat } \\
\text { preeklampsia }\end{array}$ & N & PEB \\
\hline Ya & 8 & 25 \\
Tidak & 24 & 75 \\
Total & 32 & 100 \\
\hline
\end{tabular}

Berdasarkan Tabel 5, ibu hamil dengan PEB paling banyak pada ibu dengan IMT $\geq 25$ (overweight) yaitu berjumlah 36 orang $(55,4 \%)$

Berdasarkan Tabel 6, ibu hamil dengan PEB paling banyak pada ibu tanpa riwayat hipertensi kronik yaitu 58 orang $(89,2 \%)$.

Tabel 5. Hasil distribusi penderita PEB berdasarkan IMT.

\begin{tabular}{ccc}
\hline IMT & \multicolumn{2}{c}{ PEB } \\
& $\mathbf{N}$ & $\mathbf{\%}$ \\
\hline$<18,5$ & 0 & 0 \\
$18,5-24,99$ & 8 & 12,3 \\
$\geq 25$ & 36 & 55,4 \\
$\geq 30$ & 21 & 32,3 \\
Total & 65 & 100 \\
\hline
\end{tabular}

Tabel 6. Hasil distribusi penderita PEB berdasarkan riwayat hipertensi kronik

\begin{tabular}{ccc}
\hline \multirow{2}{*}{ Hipertensi kronik } & \multicolumn{2}{c}{ PEB } \\
& N & \% \\
\hline Ya & 7 & 10,8 \\
Tidak & 58 & 89,2 \\
Total & 65 & 100 \\
\hline
\end{tabular}

Berdasarkan Tabel 7, luaran ibu pada kehamilan dengan PEB terdiri atas 1 mortalitas ibu (1,5\%), 3 sindrom HELLP $(4,6 \%), 3$ gangguan penglihatan $(4,6 \%), 4$ eklampsia $(6,2 \%), 1$ rawat ICU $(1,5 \%)$, dan 1 sepsis $(1,5 \%)$.

Tabel 7. Hasil distribusi luaran ibu pada kehamilan dengan PEB

\begin{tabular}{cccc}
\hline \multirow{2}{*}{ Luaran ibu } & & PEB & \% \\
\hline Mortalitas & Ya & 1 & 1,5 \\
& Tidak & 64 & 98,5 \\
Sindrom HELLP & Ya & 3 & 4,6 \\
& Tidak & 62 & 95,4 \\
Gangguan & Ya & 3 & 4,6 \\
penglihatan & Tidak & 62 & 95,4 \\
Eklampsia & Ya & 4 & 6,2 \\
& Tidak & 61 & 93,8 \\
Rawat ICU & Ya & 1 & 1,5 \\
& Tidak & 64 & 98,5 \\
Sepsis & Ya & 1 & 1,5 \\
& Tidak & 64 & 98,5 \\
Total & & 65 & 100 \\
\hline
\end{tabular}

Berdasarkan Tabel 8, luaran perinatal pada kehamilan dengan PEB terdiri atas 3 kematian perinatal $(4,6 \%)$, 4 IUGR $(6,2 \%)$, 23 BBLR $(35,4 \%), 5$ asfiksia AS 10 menit $(7,7 \%), 13$ gawat janin (20\%), dan 17 kelahiran prematur $(26,2 \%)$.

Tabel 8. Hasil distribusi luaran perinatal pada kehamilan dengan PEB

\begin{tabular}{cccc}
\hline \multicolumn{2}{c}{ Luaran perinatal } & \multicolumn{2}{c}{ PEB } \\
& Ya & \% \\
\hline Mortalitas & Ya & 3 & 4,6 \\
IUGR & Tidak & 62 & 95,9 \\
& Ya & 4 & 6,2 \\
BBLR & Tidak & 61 & 93,8 \\
& Ya & 23 & 35,4 \\
Asfiksia AS10 & Tidak & 42 & 64,6 \\
& Ya & 5 & 7,7 \\
Gawat janin & Tidak & 60 & 92,3 \\
& Ya & 13 & 20 \\
Prematur & Tidak & 52 & 80 \\
& Ya & 17 & 26,2 \\
& Tidak & 48 & 73,8 \\
Total & & 65 & 100 \\
\hline
\end{tabular}

\section{BAHASAN}

Pada preeklampsia terdapat beberapa faktor yang berisiko untuk kejadian 
preeklampsia, salah satunya ialah faktor usia. Usia ibu yang berisiko menderita preeklampsia ialah kelompok usia $<20$ tahun dan $>35$ tahun. Usia kehamilan $<20$ tahun memiliki keadaan alat reproduksi belum siap untuk menerima kehamilan sehingga meningkatkan terjadinya komplikasi kehamilan dalam bentuk preeklampsia dan usia ibu >35 tahun berisiko untuk terjadinya preeklampsia karena pada usia ini terjadi peningkatan kerusakan endotel vaskular akibat proses penuaan dan terjadinya obstruksi pada lumen arteriolar oleh aterosis. ${ }^{12}$ Hal ini berbeda dengan hasil penelitian pada Tabel 1 yang justru memperlihatkan bahwa ibu hamil dengan PEB paling banyak pada usia ibu 20-35 tahun yaitu 45 orang $(69,2 \%)$, begitupun hasil yang dilaporkan oleh peneliti sebelumnya pada tahun 2015. ${ }^{11}$ Namun, besarnya distribusi pada kelompok usia 2035 tahun ini tidak berarti tingginya risiko kelompok usia tersebut tetapi disebabkan karena tingginya proporsi persalinan pada kelompok usia tersebut.

Tabel 2 memperlihatkan bahwa ibu hamil dengan PEB pada primigravida lebih banyak yaitu 33 orang $(50,8 \%)$ dibandingkan dengan multigravida yang hanya 32 orang $(49,3 \%)$. Hasil ini sama dengan hasil penelitian pada tahun sebelumnya yang mendapatkan kehamilan pertama lebih dominan pada PEB. ${ }^{11}$ Hal ini berkaitan dengan adanya suatu mekanisme imunologik disamping endokrin dan genetik dan pada kehamilan pertama pembentukan blocking antibodies terhadap antigen plasenta belum sempurna, yang makin sempurna pada kehamilan berikutnya. ${ }^{13}$

Dekker dan Robillard ${ }^{14}$ melaporkan bahwa risiko preeklampsia semakin meningkat sesuai dengan lamanya interval dengan kehamilan pertama (1,5 setiap 5 tahun jarak kehamilan pertama dan kedua; $\mathrm{p}<0,0001)$. Sependapat dengan laporan tersebut, hasil penelitian pada Tabel 3 memperlihatkan bahwa dari seluruh ibu dengan PEB yang memiliki jarak kehamilan (multigravi-da $=32$ ), jarak paritas $\geq 5$ tahun $(65,6 \%)$ lebih dominan dibandingkan jarak paritas $\leq 2$ tahun $(6,3 \%)$ dan 2-5 tahun $(28,1 \%)$.

Riwayat preeklampsia pada kehamilan sebelumnya merupakan faktor risiko utama. Menurut Duckit, risiko meningkat hingga 7 kali lipat (RR 7,19 95\%CI 5,85-8,83) pada ibu dengan riwayat preeklampsia sebelumnya. ${ }^{15}$ Hasil penelitian pada Tabel 4 memperlihatkan bahwa dari seluruh ibu hamil dengan PEB yang memiliki riwayat kehamilan (multigravida $=32$ ), didapatkan ibu dengan riwayat preeklampsia sebanyak 8 orang $(25 \%)$.

Tabel 5 memperlihatkan bahwa ibu hamil dengan PEB paling banyak disertai dengan overweight yaitu berjumlah 36 orang $(55,38 \%)$. Hal ini sesuai dengan penelitian sebelumnya di RSUP Prof. Dr. R. D. Kandou Manado periode 2015 yang melaporkan bahwa overweight dan obesitas lebih dominan terjadi pada pasien preeklampsia. ${ }^{11}$ Hal ini dikarenakan obesi-tas atau tingginya IMT berhubungan dengan resistensi insulin yang juga merupakan faktor risiko preeklampsia. ${ }^{16}$

Hasil penelitian menunjukkan bahwa ibu hamil dengan PEB yang memiliki riwayat hipertensi kronik sebanyak 8 orang (12,31). Hasil ini didukung oleh penelitian Chappell et al. pada 861 wanita dengan hipertensi kronik, didapatkan insiden preeklampsia superimposed sebesar 22\% $(n=180)$ dan hampir setengahnya adalah preeklampsia onset dini $(<34$ minggu) dengan luaran maternal dan perinatal yang lebih buruk. $^{17}$

Ibu dengan PEB biasanya disertai dengan komplikasi pada ibu hamil yang berisiko meningkatkan mortalitas dan morbiditas ibu. Komplikasi yang biasa terjadi pada ibu hamil yaitu sindrom HELLP, gagal ginjal akut, gangguan penglihatan, eklampsia, perawatan ICU, perdarahan postpartum, sepsis, edema serebri, perdarahan serebral bahkan sampai pada kematian. ${ }^{18,19}$

Hasil penelitian memperlihatkan bahwa dari seluruh ibu yang menderita PEB terdapat 1 kasus mortalitas ibu (1,6\%). Hasil ini sejalan dengan penelitian yang dilakukan di RSUP Dr. Kariadi Semarang yang juga menemukan 1 kasus kematian 
ibu. $^{20}$ Hal ini dikarenakan efek sekunder dari preeklampsia yang biasanya terjadi akibat eklampsia, tekanan darah yang tidak terkontrol, atau inflamasi sistemik dan juga sering disebabkan oleh perdarahan serebral. $^{21}$

Salah satu komplikasi yang berbahaya dan lazim ditemukan pada ibu dengan PEB ialah sindrom HELLP yang disebabkan oleh partikel sinsisiotrofoblas dan substansi dari plasenta yang berinteraksi dengan imun sistem ibu dan sel endotel vaskuler. ${ }^{22}$ Teori ini sesuai dengan hasil penelitian yang menunjukkan bahwa dari seluruh ibu yang menderita PEB terdapat 3 ibu $(4,6 \%)$ dengan sindrom HELLP.

Tabel 8 memperlihatkan bahwa dari seluruh ibu hamil dengan PEB terdapat 3 ibu (4,6\%) yang mengalami gangguan penglihatan. Penelitian yang serupa dilakukan di RSUP Dr. Kariadi Semarang dengan persentase hasil yang lebih tinggi yaitu $43,1 \% .{ }^{20}$ Besarnya perbedaan persentase ini mungkin disebabkan karena banyaknya pasien yang menolak untuk dilakukan pemeriksaan mata. Gangguan penglihatan yang biasa muncul ialah diplopia, penglihatan kabur, dan ablasio retina, sedangkan kebutaan lebih jarang terjadi. ${ }^{19}$

Komplikasi dengan persentase tertinggi yang ditemukan pada hasil penelitian ini ialah eklampsia. Dari seluruh ibu yang menderita PEB terdapat 4 ibu $(6.2 \%)$ dengan komplikasi ini. Penelitian yang serupa di RSUP Dr. Kariadi Semarang mendapatkan hasil $8,4 \%$ ibu dengan eklampsia. ${ }^{20}$ Eklampsia atau periode kejang eklamptik ini sebagai salah satu komplikasi dari preeklampsia yang disebabkan oleh beberapa hal, seperti edema serebri, perdarahan intraserebral, infark serebral, vasospasme serebral, dan ensefalopati hipertensi. $^{23}$

Komplikasi preeklampsia pada ibu hamil sangat beragam, dan banyak diantara nya menuntut ibu untuk dirawat dengan alat penunjang kehidupan yang berada di ICU. ${ }^{19}$ Salah satu contoh yang diberikan ialah komplikasi preeklampsia berupa periode koma eklamptik. Sesuai dengan hasil penelitian yang menunjukkan bahwa dari seluruh ibu yang menderita PEB terdapat $1 \mathrm{ibu}(1.5 \%)$ yang mendapatkan perawatan ICU.

Hasil penelitian memperlihatkan bahwa dari seluruh ibu yang menderita PEB terdapat $1 \mathrm{ibu}(1,5 \%)$ yang mengalami sepsis. Hasil ini sesuai dengan penelitian di Amerika Serikat yang menyatakan bahwa ibu hamil dengan preeklampsia memiliki risiko yang lebih besar untuk mengalami severe sepsis, perdarahan postpartum, dan komplikasi pada luka. Ibu dengan preeklampsia juga memiliki risiko untuk mengalami syok septik 3 kali lebih besar daripada risiko untuk mengalami severe sepsis. $^{24}$

Preeklampsia berat tidak hanya terjadi pada ibu hamil namun juga terjadi pada luaran perinatal. Luaran perinatal yang biasa terjadi yaitu BBLR, IUGR, asfiksia, gawat janin, kelahiran prematur, bahkan sampai kematian. ${ }^{21,25}$

Hasil penelitian ini memperlihatkan bahwa dari seluruh bayi yang dilahirkan dari ibu dengan PEB terdapat 3 kasus mortalitas perinatal $(4,6 \%)$. Penelitian yang serupa di RSUP Dr. Kariadi Semarang mendapatkan 2 kasus kematian perinatal $(3,4 \%) .{ }^{20}$ Komplikasi kematian perinatal ini dihubungkan dengan fasilitas pelayanan kesehatan yang masih kurang seperti tidak adanya akses neonatal intensive care unit. $^{21,25}$

Ibu dengan preeklampsia memiliki risiko 2,7 kali lebih besar untuk melahirkan bayi dengan pertumbuhan terhambat dibandingkan ibu dengan kehamilan tanpa komplikasi. Preeklampsia sebagai komplikasi kehamilan dengan karakter penurunan aliran darah dan iskemi uteroplasenta merupakan faktor risiko yang paling dominan dalam terjadinya intra uterine growth restriction. Srinivas et al. mengemukakan bahwa ibu dengan preeklampsia memiliki risiko 2,7 kali lebih besar untuk melahirkan bayi dengan pertumbuhan terhambat dibandingkan ibu dengan kehamilan tanpa komplikasi. Sesuai dengan hasil penelitian memperlihatkan bahwa dari ibu yang menderita preeklampsia berat terdapat 4 bayi $(6,2 \%)$ dengan IUGR. ${ }^{9,26}$ 
Pada preeklampsia terjadi gangguan pada sistem uteroplasenta yang memiliki peran penting untuk suplai darah dan nutrisi pada janin sehingga terhambatnya pertumbuhan dan berat badan lahir menjadi tidak optimal yang berakibat munculnya luaran perinatal berupa bayi dengan berat badan lahir rendah. ${ }^{26}$ Hasil penelitian memperlihatkan bahwa dari ibu yang menderita PEB terdapat 23 bayi dengan BBLR $(35,4 \%)$. Menurut penelitian lain di RSUD Undata Palu, terdapat hubungan bermakna antara preeklampsia dengan BBLR dan merupakan faktor risiko 2,48 kali lebih besar penyebab BBLR. ${ }^{27}$

Penelitian yang dilakukan di RSUD Dr. Moewardi Surakarta mendapatkan hasil yang bermakna dengan nilai odds ratio $(\mathrm{OR})=3,527$ yang berarti ibu penderita preeklampsia berat memiliki risiko 3,5 kali pada bayinya untuk mengalami asfiksia. ${ }^{28}$ Penelitian tersebut didukung oleh hasil penelitian pada Tabel 8 yang menemukan bahwa dari ibu yang menderita preeklampsia berat terdapat bayi yang mengalami asfiksia berjumlah 5 bayi $(7,7 \%)$.

Hipoperfusi uteroplasenta pada preeklampsia berefek pada terganggunya pasokan oksigen dari ibu kepada janin. Jika kondisi ini terus menerus berlanjut dan proses adaptasi yang diupayakan oleh janin tidak dapat terus berlangsung maka refleks vagal muncul dan menyebabkan janin mengalami bradikardi yang nampak sebagai kondisi gawat janin. $^{29}$ Sesuai dengan teori tersebut, hasil penelitian pada Tabel 8 memperlihatkan bahwa dari ibu yang menderita PEB ditemukan bayi dengan gawat janin berjumlah 13 (20\%).

Preeklampsia memberikan pengaruh pada pasokan darah dari ibu ke plasenta, yang dapat menyebabkan buruknya pertumbuhan janin dalam kandungan ibu dan dapat memicu terjadinya persalinan prematur. Hasil penelitian pada Tabel 8 memperlihatkan bahwa dari ibu yang menderita PEB terdapat bayi dengan kelahiran prematur sebanyak 17 orang (26,2\%). Penelitian lain di RSUP Dr. Kariadi Semarang menemukan hasil 24,1\% luaran perinatal berupa kelahiran prematur. ${ }^{20}$

\section{SIMPULAN}

Berdasarkan hasil penelitian ini dapat disimpulkan bahwa karakteristik ibu hamil dengan PEB paling banyak pada ibu dengan usia 20-35 tahun, primigravida, jarak hamil $\geq 5$ tahun, tanpa riwayat preeklampsia (75\%), overweight, dan tanpa riwayat hipertensi kronik.

Luaran ibu pada kehamilan dengan PEB ditemukan mortalitas ibu, Sindrom HELLP, gangguan penglihatan, eklampsia, rawat ICU, dan sepsis.

Luaran perinatal pada kehamilan dengan PEB ditemukan mortalitas perinatal, IUGR, BBLR, asfiksia, gawat janin, dan prematur.

\section{SARAN}

Diharapkan kepada institusi rumah sakit terkhusus bagian administrasi rumah sakit untuk lebih mengklasifikasikan dan melengkapi berkas rekam medik pasien karena terdapat ketidaksesuaian.

Disarankan agar tenaga kesehatan meningkatkan sosialisasi berupa penyuluhan tentang komplikasi kehamilan dengan preeklampsia agar dapat mengurangi angka mortalitas ibu dan perinatal.

Diharapkan untuk penelitian lebih lanjut mencari hubungan analisis pada beberapa variabel.

\section{DAFTAR PUSTAKA}

1. Pusat Data dan Informasi Kementerian Kesehatan RI. Situasi Kesehatan Ibu. Jakarta: Kemenkes RI, 2014.

2. Kementerian Kesehatan Repubik Indonesia. Profil Kesehatan Indonesia 2015. Jakarta: Kemenkes RI, 2016.

3. Badan Pusat Statistik. Profil Penduduk Indonesia Hasil SUPAS 2015. Jakarta: Badan Pusat Statistik, 2016.

4. Dinas Kesehatan Provinsi Sulawesi Utara. Profil Kesehatan Provinsi Sulawesi Utara 2015. Manado: Dinas Kesehatan Provinsi Sulawesi Utara, 2016.

5. Djaja S, Irianto J, Pangaribuan L. Tren lahir mati dan kematian neonatal di Indonesia, Hasil Survey Kesehatan Tahun 1995-2007. Jurnal Ekologi Kesehatan. 2009;8(2):937-45. 
6. Paley C, Spradley FT, Warrington JP, George EM, GrangerJP. Pathophysiology of Hypertension in Preeclampsia: A lesson in Integrative Physiology. Acta Physiol (Oxf). 2013;208(3):224-233.

7. Uzan J, Carbonnel M, Piconne O, Asmar R, Ayoubi JM. Pre-eclampsia pathophysiology, diagnosis, and management. Vasc Health Risk Manag. 2011; 7: 467-74.

8. Sultana AJ. Risk factor for preeclampsia and its perinatal outcome. Scholars Research Library. 2013;4(10):1-5.

9. Backes CH, Markham K, Moorehead P, Cordero L, Nankervis CA, Giannone PJ. Maternal preeclampsia and neonatal outcome. J Pregnancy. 2011;2011. Article ID 214365

10. Lombo GE. Karakteristik ibu hamil dengan preeklampsia di RSUP Prof. Dr. R. D. Kandou Manado periode 1 Januari-31 Desember 2015 [Skripsi]. Manado: Fakultas Kedokteran Universitas Sam Ratulang; 2016.

11. Warouw PC. Karakteristik preeklampsia di RSUP Prof. Dr. R. D. Kandou Manado periode 1 Januari-31 Desember 2014. Manado: Fakultas Kedokteran Universitas Sam Ratulangi; 2015.

12. Robson E. Patologi dalam kehamilan. Manajemen dan Asuhan Kebidanan. Jakarta: EGC, 2012.

13. Sudinaya IP. Insiden preeklamsi- eklamsi di RSU Tarakan Kalimantan Timur tahun 2000 [tidak dipublikasikan]. Kalimantan Timur: Bagian Obstetri Ginekologi, 2000.

14. Dekker G, Robillard PY. The birth interval hypothesis-does it really indicate the end of paternity hypothesis? J Reprod Immunol. 2003;59:245-51.

15. Duckitt K, Harrington D. Risk factors for preeclampsia at antenatal booking: systematic review of controlled studies. BMJ. 2005;330:549-50.

16. Wolf M, Sandler L, Munoz K, Hsu K, Ecker JL, Thadhani R. First trimester insulin resistance and subsequent preeclampsia: a prospective study. J Clin Endocrinol Metab. 2002;87;:1563-8.

17. Conde-Agudelo A, Villar J, Lindheimer
M. World Health Organization systematic review of screening tests for pre-eclampsia. Obstet Gynecol. 2004;104: 1367-91.

18. Sibai BM. Magnesium su;phate prophylaxis in preeclampsia: evidence from randomized trials Clin Obstet Gynecol. 2005;48:478-88.

19. Leveno KJ, Cunningham FG, Gant NF, Alexander JM, Bloom SL, Casey BM, et al. Obstetri Williams. Jakarta: EGC, 2009.

20. Akip SD. Luaran maternal dan perinatal pada ibu hamil dengan preeklampsia berat periode 1 Januari 2014-31 Desember 2014. Semarang: Fakultas Kedokteran Universitas Diponegoro; 2015.

21. Ghulmiyyah L, Sibai B, editors. Maternal Mortality from Preeclampsia/ Eclampsia. Seminars in Perinatoloy; Elsevier, 2012.

22. Simetka O, Klat J, Gumulec J, Dolezalkova E, Salounova D, Kacerovsky M. Early identification of women with HELLP syndrome who need plasma exchange after delivery. Transfus Apher Sci. 2015;52(1):54-9.

23. Anggraeni W, Pramono BA. Analisis faktor risiko terhadap luaran maternal dan perinatal pada kasus eklampsia di RSUP Dr Kariadi Tahun 2011-2012: Semarang: Faculty of Medicine Diponegoro University; 2013.

24. Acosta CD, Knight M, Lee HC, Kurinczuk JJ, Gould JB, Lyndon A. The continuum of maternal sepsis severity: incidence and risk factors in a population-based cohort study. PloS one. 2013;8(7):e67175.

25. Ngoc NTN, Merialdi M, Abdel-Aleem H, Carroli G, Purwar M, Zavaleta N, et al. Causes of stillbirths and early neonatal deaths: data from 7993 pregnancies in six developing countries. Bull WHO. 2006;84(9): 699-705.

26. Wati LK. Hubungan antara preeklampsia/ eklampsia dengan kejadian berat badan lahir rendah (BBLR) Di RSUD Dokter Soedarso Pontianak Tahun 2012. Jurnal Mahasiswa PSPD FK Universitas Tanjungpura. 2013;3(1).

27. Mallisa B. Hubungan antara preeklampsia 
Kalam, Wagey, Mongan: Luaran ibu dan perinatal pada kehamilan dengan ...

dengan kejadian BBLR di RSUD Undata Palu periode 2011-2012. Palu: Fakultas Kedokteran Universitas Tadulako; 2014.

28. Heriyanti O. Hubungan antara preeklampsia berat dengan asfiksia perinatal di RSUD Dr. Moewardi Surakarta periode Agustus-Oktober
2008. Surakarta: Fakultas Kedokteran Universitas Sebelas Maret; 2009.

29. Bawono BS. Gambaran analisis gas darah arteri umbilikalis neonatus pada preeklampsia berat. Semarang: Program Pasca Sarjana Universitas Diponegoro; 2005. 